\title{
Molar ratios of uracil to thymine in algae samples as an indicator of algae growth rate and its application to cyanobacteria-dominated waters
}

\author{
Qinghui Huang'*, Mengtan Liu', Penghui Li' ${ }^{1}$, Dong Zhang ${ }^{2}$ \\ ${ }^{1}$ Key Laboratory of Yangtze River Water Environment of the Ministry of Education, College of Environment Science and Engineering, \\ Tongji University, Shanghai 200092, China \\ ${ }^{2}$ Shanghai Urban Water Resources Development and Utilization National Engineering Center Co.Ltd., Shanghai 200082, China \\ ${ }^{*}$ Corresponding author, E-mail: qhhuang@tongji.edu.cn
}

\begin{abstract}
Phytoplankton growth rates are highly dynamic during critical ecological periods, and are of great significance in monitoring programmes as an early warning signal of harmful algal bloom. However, it was still difficult to obtain in situ algal growth rates in a broad spatiotemperal scale. Here we aimed to explore the potential of estimating algal growth rate (AGR) by using a cellular nucleobasederived ratio. AGR in batch cultures of Microcystis aeruginosa (FACHB-905) was calculated by the daily increment of in vivo chlorophyll fluorescence, and culture cells were collected at different growth phase for nucleobase analysis. The specific growth rate of algae cells was found to increase as a logarithmic function of the molar ratio of uracil to thymine in culture cells, and the inflection point of the fitting curve could be a critical value for the exponential phase of algal growth. In a case study conducted in a large reservoir in Yangtze estuary, AGR was estimated from 0.24 to 0.52 day $^{-1}$ during a Microsystis-dominated period in October 2014 and one site was recognized at high risk of algal blooming. In conclusion, the ratio of uracil to thymine has potential use in estimating of the AGR, and is promising in the analysis on spatiotemporal dynamics of $i n$ situ growth rates of dominant algae.
\end{abstract}

Key words: algal growth rate, cyanobacteria, harmful algal bloom, nucleobase, phytoplankton.

Abbreviations: AGR, algal growth rate; AIC, Akaike's information criteria; [U]/[T], molar ratios of uracil to thymine.

\section{Introduction}

Phytoplankton, as the basis of food webs in fresh-water ecosystems, has a critical role in primary production and nutrient cycling (Dawes 1998; Paerl et al. 2001). However, algal blooms can cause adverse effects on aquatic ecosystems, including depletion of oxygen, fishe mortality, production of algal toxins, and risk to human health (Stolte, Garcés 2006; Ma et al. 2013; Ma et al. 2015). Cyanobacteria, as the ancient microalgae species leading to algal blooms, have long been recognized as a water-quality problem in lakes and reservoirs due to their potential toxicity and their capacity to cause off-flavor in drinking water (Wang et al. 2013). Moreover, as far as the water quality management is concerned, it is important to forecast the outbreak location and time of harmful algal blooms in large lakes or reservoirs (Chan et al. 2004). Algal growth characteristics need to be obtained with a relatively high spatial and temporal resolution. Typically, the measurement of in situ growth rates, reflecting the actual growth characteristics of phytoplankton, has been one of considerable issues and the toughest questions in exploring the succession of phytoplankton communities and understanding the formation of phytoplankton blooms comprehensively.
So far, algal growth rate (AGR) has been estimated by a wide variety of methods, including the frequency of dividing cell technique (McDuff, Chisholm 1982; Campbell, Carpenter 1986), in situ incubation of an enclosed water column (Elser 1992), cell cycle analysis methods (Chang, Dam 1993), flow cytometry in combination with isotope analysis (Pel et al. 2004), ${ }^{14} \mathrm{C}$ labeling of chlorophyll and carotenoids (Redalje, Laws 1981; Gieskes, Kraay 1989; $\mathrm{Xu}$, Huang 2010), nucleic acid-derived indices (i.e. RNA: DNA ratios, RNA: protein and rRNA) (Dortch et al. 1983; Loughna, Goldspink 1984; Hou et al. 2008) and others. However, some methods are not really appropriate for the measurement of in situ growth rates of algae. The frequency of dividing cells technique and in situ incubation method have been applied to some studies on Lake Biwa in a eutrophication period, Sargasso and Caribbean Seas in the USA, and Three-Gorges Reservoir in China (Braunwarth, Sommer 1985; Tsujimura 2003; Yamamoto, Tsukada 2009; Wang et al. 2010; ). However, the frequency of dividing cells technique has been restricted to widespread application due to the considerable labour and taxonomic skill required. Typically, hourly or bihourly sampling and measuring for at least $24 \mathrm{~h}$ are required in the above methods, so both field work and laboratory work are time-consuming, leading to 


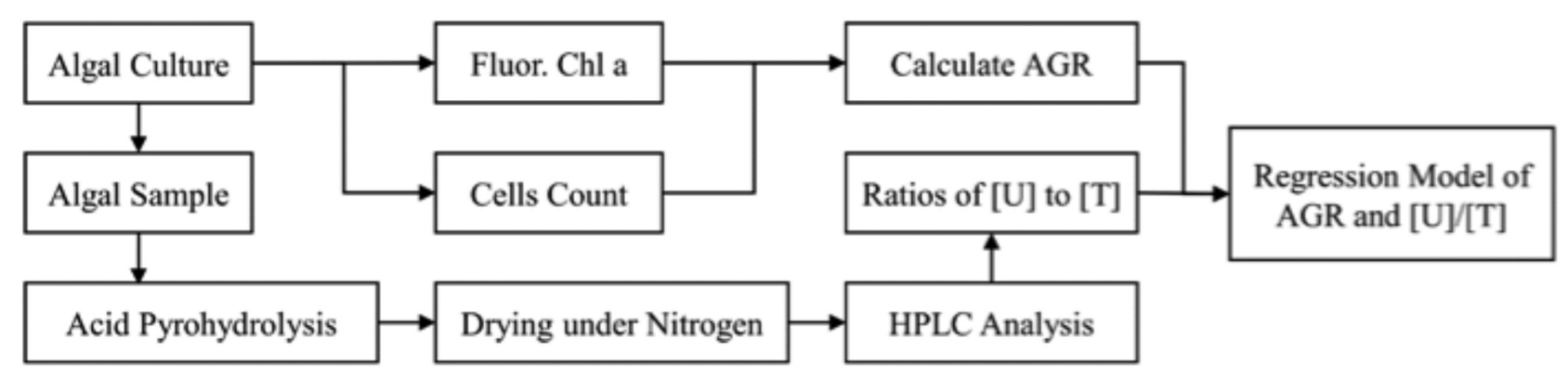

Fig. 1. Scheme of experimental design and nucleobase analysis.

the extremely overstrain of monitoring and experimental work in the field. These methods have not been applied on a large spatial and temporal scale due to the difficulties in acquiring high-frequency data of AGR.

Algal development may be described by AGR estimation based on some indices derived from nucleic acids. The amount of RNA directly involved in protein synthesis is known to vary with age, life-stage, organism size, diseasestate and with changing environmental conditions. In the growth process of microalgae cells, the speed of protein synthesis depends on the content of RNA in cells (Chícharo, Chícharo 2008). Apparently, to some extent, the cellular RNA content (e.g., content of rRNA; Binder, Liu 1998) can reflect growth rates of algae as a nucleic derived index. However, the amount of DNA, the primary carrier of genetic information, is stable under changing environmental situations within the somatic cells of a species. The ratio of RNA to DNA, as an eco-physiological index of growth rate, has been widely used to evaluate growth status of aquatic organisms under a given environmental condition in aquatic ecology (Chícharo, Chícharo 2008). However, there is still no uniform or optimal method for the extraction and quantitative analysis of RNA and DNA in algae cells at present (Dortch et al. 1983; Berges et al. 2002; Greco et al. 2014). The limited application of RNA to DNA ratios was largely attributed to the differences in the RNA and DNA contents measured by different classical analytical protocols or different laboratories (Dortch et al. 1983; Kerkhof, Ward 1993; Caldarone et al. 2006).

In order to explore the problems mentioned above, batch culture experiments of Microcystis aeruginosa in the laboratory were conducted at first, and then a non-linear regression model was built to describe the relationship between a cellular nucleobase-derived indicator ([U]/[T] ratio) and the growth rate of algae cells. We also attempted to use the algorithm above to retrieve the in situ growth rate of phytoplankton communities in a freshwater ecosystem dominated by cyanobacteria.

\section{Materials and methods}

\section{Strains, cultures and experimental design}

The unicellular cyanobacteria Microcystis aeruginosa
(FACHB-905) used in the culture experiments (Fig. 1) was obtained from the Freshwater Algal Culture Collection at the Institute of Hydrobiology of the Chinese Academy of Sciences, Wuhan, China. Batch culture of the strains was maintained in a culture medium for a algal growth potential test (Jin, Tu 1990). The $\mathrm{pH}$ of cultures was adjusted to $7.5 \pm$ 0.1 with $1 \mathrm{~mol} \mathrm{~L}^{-1} \mathrm{HCl}$ and $1 \mathrm{~mol} \mathrm{~L}^{-1} \mathrm{NaOH}$. Algae cells in exponential growth phase were collected via centrifugation at $3500 \mathrm{r} \mathrm{min}^{-1}$ for $10 \mathrm{~min}$, supernatant was discarded, the and algal cells were then suspended with sterile deionized water to remove the nutrients and other substances. The above process was repeated three times, and finally diluted with aseptically deionized water. Then algae cells were inoculated into $500 \mathrm{~mL}$ sterile Erlenmeyer flasks containing approx. $200 \mathrm{~mL}$ of culture medium. The initial concentrations of algae cells was about $10^{5}$ cells $\mathrm{mL}^{-1}$.

Six treatments (A1 to A6) were designed for the culture experiments in parallel with different concentrations of nitrogen and phosphorus (Table 1), according to their concentrations in Qingcaosha Reservoir. Each treatment had a desired concentration of nitrogen and phosphorus by adding the required amount of $\mathrm{NaNO}_{3}$ and $\mathrm{K}_{2} \mathrm{HPO}_{4}$. Algal cultures were growing at $28 \pm 1{ }^{\circ} \mathrm{C}$ illuminated in a $14 / 10 \mathrm{~h}$ of light/dark cycle at irradiance of $46.25 \mu \mathrm{mol} \mathrm{m}^{-2} \mathrm{~s}^{-1}$. Each treatment group was performed in triplicate and the whole incubation period lasted 14 days. The time of inoculation of algae was regarded as the start of the experiment (day 0 ). Cultures were manually shaken three times each day and rearranged randomly to reduce effects caused by minor differences in photo irradiance.

Table 1. Initial concentration of nitrogen and phosphorus in different treatments

\begin{tabular}{lcc|}
$\begin{array}{l}\text { Treatment } \\
\text { No. }\end{array}$ & $\begin{array}{c}\text { Total nitrogen } \\
\left(\mathbf{m g ~ L}^{-1}\right)\end{array}$ & $\begin{array}{c}\text { Total phosphorus } \\
\left(\mathbf{m g ~ L}^{-1}\right)\end{array}$ \\
A1 & 0.420 & 0.0186 \\
A2 & 1.05 & 0.0465 \\
A3 & 4.20 & 0.186 \\
A4 & 8.40 & 0.372 \\
A5 & 16.8 & 0.744 \\
A6 & 42.0 & 1.86 \\
\hline
\end{tabular}




\section{Measurement of chlorophyll a and calculation of growth rate}

The chlorophyll a concentrations of six treatment groups above were determined by means of fluorescence measurements. Nonfixed samples were measured in triplicate using a Phytoplankton Analyzer (PhytoPAM, Heinz Walz GmbH, Germany) during the entire experimental phase $\left(R^{2}=0.98, n=23, P<0.001\right.$, data not shown). Also each algal culture sample was corrected for background fluorescence by a filtered $(0.22 \mu \mathrm{m})$ algae sample (25 mm GF/F filter, Whatman). Moreover, additional chlorophyll-a extractions were performed to calibrate the above fluorescence data at various days throughout the experimental period. Chlorophyll $a$ was extracted using the $90 \%(\mathrm{v} / \mathrm{v})$ hot ethanol extraction method (Pápista et al. 2002). The data above was used to determine growth curves in all treatment groups. In general, the growth of microalgae could be modeled with four different phases: lag phase, exponential phase, stationary phase, and death phase.

The instantaneous growth rate, used to characterize the population growth, was defined here as the daily averaged growth rate $\left(r\right.$ day $\left.^{-1}\right)$. We supposed that the mortality of algae was zero in the exponential growth phase. At this time, the instantaneous growth rate was equal to specific growth rate $\mu$ (Hoffmann, Poorter 2002; Monon 1949). Therefore, we calculated $\mu$ under each set of treatment conditions according to the following equation (Ma et al.2015):

$$
\left.\mu=r=\left(\ln X_{2}-\ln X_{1}\right) /\left(t_{2}-t_{1}\right) \quad \text { (Equation } 1\right) \text {, }
$$

where $X_{2}$ and $X_{1}$ are the concentration of chlorophyll $a$ ( $\mu \mathrm{g}$ $\left.\mathrm{L}^{-1}\right)$ at time $t_{2}$ and $t_{1}$ (days), respectively.

Doubling time, $T_{2}$, was calculated from an estimate of $r$ with use of the following equation:

$$
T_{2}=\ln (2) / r
$$

(Equation 2).

Doublings per day $(k)$ was be calculated directly from the concentration of chlorophyll $a$ with use of the following equation:

$$
k=\log _{2}\left(\mathrm{X}_{2} / \mathrm{X}_{1}\right) /\left(t_{2}-t_{1}\right)
$$

(Equation 3).

Sample collection and preparation for nucleobase analysis Diurnal variation of fluorescent chlorophyll $a$ was monitored in various treatment groups with different nutrient concentrations in order to calculate daily average growth rates of $M$. aeruginosa according to Equation 1 above. When algae cells in the culture system were in the exponential growth stage, according to the chlorophyll-a concentration, an appropriate volume of algal cultures was transferred using sterilized pipette in the clean bench. Then algal suspension was filtered through precombusted (at $450{ }^{\circ} \mathrm{C}$ for $\left.4 \mathrm{~h}\right)$ glass-fiber filters $(0.7 \mu \mathrm{m}, 47 \mathrm{~mm}$ Whatman $\mathrm{GF} / \mathrm{F}$ ) using a vacuum, and then the filters with algal cells were dried to a constant weight in the oven at $60{ }^{\circ} \mathrm{C}$. Eventually, several algal cell samples with different growth rates were obtained in the exponential growth phase from the above treatment groups.
The dried filters were weighed and placed into $3 \mathrm{~mL}$ ampules with $2 \mathrm{~mL}$ of $6 \mathrm{~mol} \mathrm{~L}^{-1} \mathrm{HCl}$ added. Aliquots of nucleic acid solutions were pipetted into ampules with sufficient concentrated $\mathrm{HCl}$ added to reach a final concentration of $6 \mathrm{~mol} \mathrm{~L} \mathrm{~L}^{-1}$. The ampules were flushed with nitrogen, flame-sealed, wrapped with aluminum foil and placed in an oven at $160{ }^{\circ} \mathrm{C}$ for $40 \mathrm{~min}$ for pyrimidine analysis (Huang et al.2012). The hydrolysate was centrifuged to remove particles, and typically $50 \mu \mathrm{L}$ of supernatant was dried under a stream of nitrogen. Twenty microliters of Milli-Q water were added to the dried hydrolysate and then samples were dried again to remove $\mathrm{HCl}$ acid.

Qingcaosha Resevior, located in the Yangtze River estuary is the lagest drinking water sources in Shanghai, China. Toxic algae blooms of $M$. aeruginosa in this reservoir would threaten the safety of the water supply in summer and autumn. As a case study, AGR was estimated by using the ratios of uracil to thymine in cellular material obtained from the Qingcaosha Reservoir. Eight samples were collected from surface water at different sites of Qingcaosha Reservoir (Fig. 2) in October, 2014. Water samples taken from four to five subsites around each sampling site were mixed into a pooled sample to minimize variation. Further sample preparation was exactly the same as for cultured algal cell samples.

\section{Analysis of nucleobases in algal cells}

The qualitative and quantitative analysis of nucleobases (Huang et al.2012) was performed with a high performance liquid chromatography system (HPLC 1200, Agilent) equipped with an autosampler, a diode-array detector and ChemStation software. A polar reverse phase column (Agilent Zorbax SB-AQ, $4.6 \mathrm{~mm} \times 150 \mathrm{~mm}, 3.5 \mu \mathrm{m}$ ) with a guard column (Agilent Zorbax SB-AQ, $4.6 \mathrm{~mm} \times 12.5$ $\mathrm{mm}, 5 \mu \mathrm{m})$ at $35{ }^{\circ} \mathrm{C}$ was used to separate nucleobases. The optimal detection wavelength was set at $262 \mathrm{~nm}$ for simultaneous detection of uracil and thymine. The dried hydrolysates were dissolved in $100 \mu \mathrm{L}$ Milli-Q water with vigorous vortexing prior to quantitative analysis of nucleobases by HPLC. Nucleobases were separated using a two-phase gradient elution with solvent A, $20 \mathrm{mmol} \mathrm{L}^{-1}$

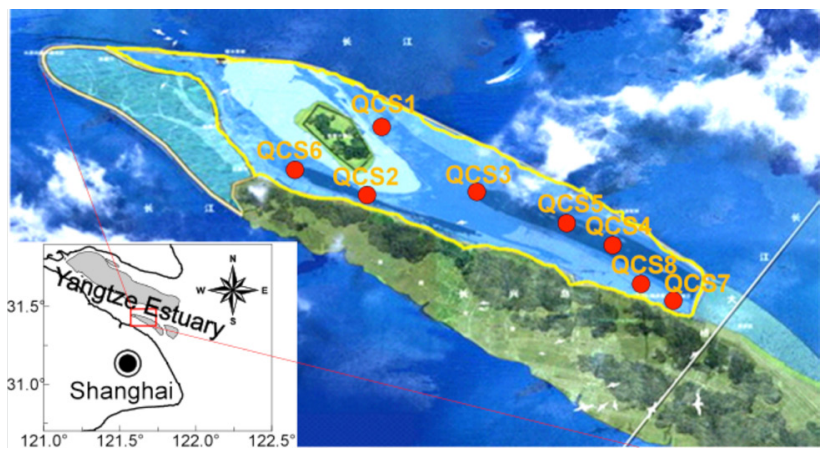

Fig. 2. Map of sampling sites (QCS1 to QCS8) in the Qingcaosha Resevior (based on Google Earth 7.1, 2016) of the Yangtze estuary. 
sodium acetate adjusted to $\mathrm{pH} 4.9$ with $30 \%(\mathrm{v} / \mathrm{v})$ acetic acid, and solvent B, $100 \%$ methanol. The flow rate of the mobile phase was $1.5 \mathrm{~mL} \mathrm{~min}^{-1}$, and the total run time was $15 \mathrm{~min}$. Samples of $20 \mu \mathrm{L}$ obtained as described above were injected for HPLC analysis. According to chromatographic peak areas of nucleobases, the molar concentrations of uracil and thymine could be calculated accurately using a formula derived from calibration curve.

Uracil (U) and Thymine (T) were purchased from Sigma-Aldrich. HPLC grade acetic acid and ammonium acetate were obtained from Dikma Technologies. HPLC grade methanol and 2-propanol were purchased from Fisher Scientific. Hydrochloric acid (Guarantee Reagent) and sodium hydroxide (Guarantee Reagent) were purchased from Sinopharm Chemical Reagent Co., Ltd (China). Milli-Q ultrapure water was produced using a Millipore purification system.

\section{Statistical analysis}

All data were collected in triplicate and presented as mean \pm standard deviation. A nonlinear regression with Origin 8.5 software (OriginLab Corporation Northampton, USA) for Windows was used to model the relationship between nucleobase ratio ([U]/[T]) and AGR. A set of three candidate models was used for the above data to model growth rates of algae: three-parameter logarithmic model (Zwietering et al. 1990), exponential growth model and three-parameter exponential model (Cloern et al. 1995; Paine et al. 2012); named $M_{1}$ to $M_{3}$ respectively (Table 2). Model selection and the estimation of model selection uncertainty were based on the information theory approach using Akaike's Information Criteria (AIC) (Katsanevakis 2006; Katsanevakis and Maravelias 2008). The three candidate models $\mathrm{M} i(i=1$ to 3 ) were fitted to all data obtained with non-linear squares, assuming additive error structure. The small-sample, bias-corrected AICc was used for model selection. Specifically, AICc $=\mathrm{AIC}+(2 \mathrm{k}(\mathrm{k}+1)) /(\mathrm{n}-\mathrm{k}-1)$, where for least squaresAIC $=\mathrm{n} \log (\log (2 \pi \mathrm{RSS} / \mathrm{n})+2 \mathrm{k}$, RSS was the residual sum of squares, $\mathrm{n}$ the number of observations, and $\mathrm{k}$ was the total

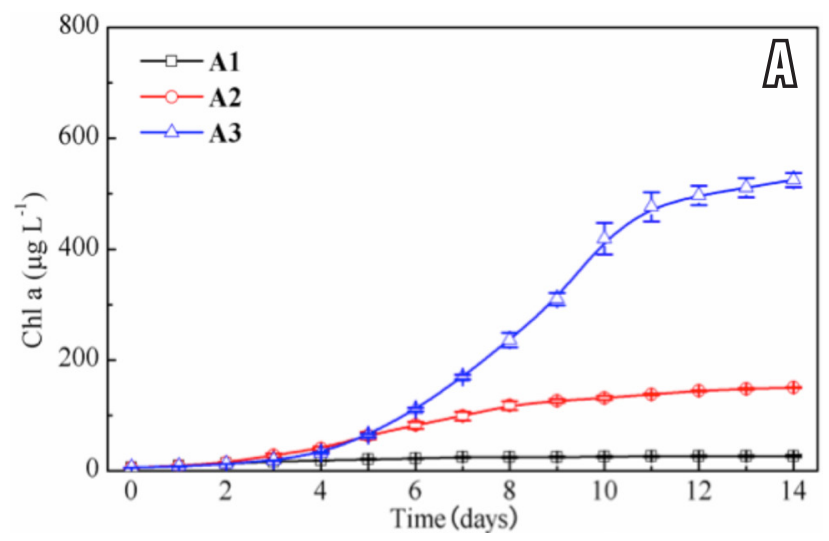

number of estimated regression parameters in the model equation plus 1 . The model with the smallest AICc value (AICc, min) was selected as the 'best' among the models tested. The AICc differences, $\Delta \mathrm{i}=\mathrm{AICc}, \mathrm{i}-\mathrm{AICc}$,min were computed over above candidate models Mi. According to Burnham, Anderson (2002), models with $\Delta i>10$ have essentially no support and might be omitted from further consideration, models with $\Delta i<2$ have substantial support, while there was considerably less support for models with $4<\Delta i<7$ (Burnham, Anderson 2002). Statistical analysis and modelling of algal growth rates were conducted with Origin 8.5 Software and the AICcmodavg packages of $\mathrm{R}$ Statistical Computing Software (version 3.2.2).

\section{Results}

\section{Algal growth curves at different nutrient levels}

Chlorophyll a concentrations of $M$. aeruginosa increased gradually at first and were stable or slightly declined in all treatment groups (Fig. 3). The algal biomass of $M$. aeruginosa increased very slowly in A1 and A2, as algal growth was limited by phosphorus concentration. There was no apparent exponential growth period for A1, while exponential growth started at day 3 for A2 after the adaptive phase. For treatment A3 with standard nutrient concentration, there were four typical algal growth phases. The growth curves for A4, A5 and A6, in which there were higher nutrient concentrations than $\mathrm{A} 3$, showed similar pattern as for $\mathrm{A} 3$, but the exponential growth period was longer in $\mathrm{A} 5$ and $\mathrm{A} 6$ than in $\mathrm{A} 3$ and $\mathrm{A} 4$.

\section{Algal growth rates at different nutrient levels}

Bell-shaped curves of algal growth rate were observed in most of the treatments (Fig. 4). There was a period when algal growth rates increased rapidly to a maximum for a couple of days, and then declined rapidly. However, some obvious differences were observed among various treatment groups with different concentrations of nutrients. There was no period of increasing growth rate in A1, which might be due to low phosphorus nutrient concentrations.

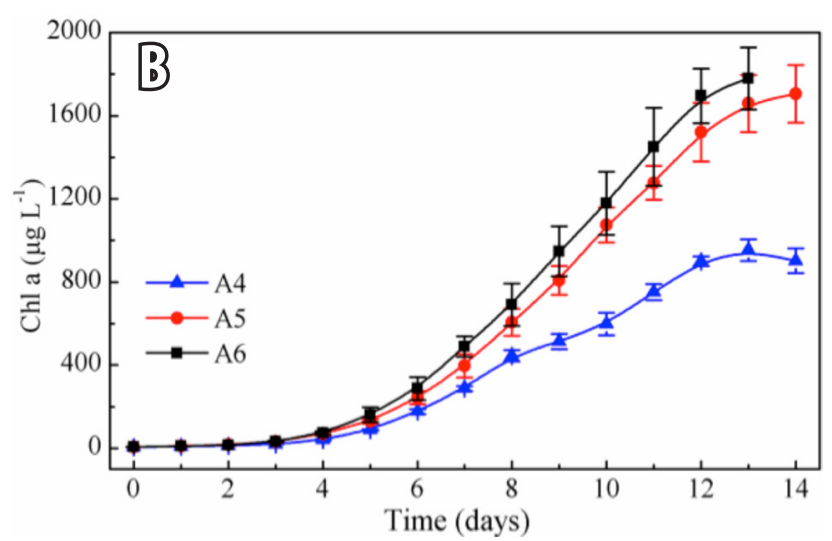

Fig. 3. Growth curves of algal cultures with different concentrations of nitrogen and phosphorus. Treatments A1, A2, A3 (A); treatments A4, A5, A6 (B). 

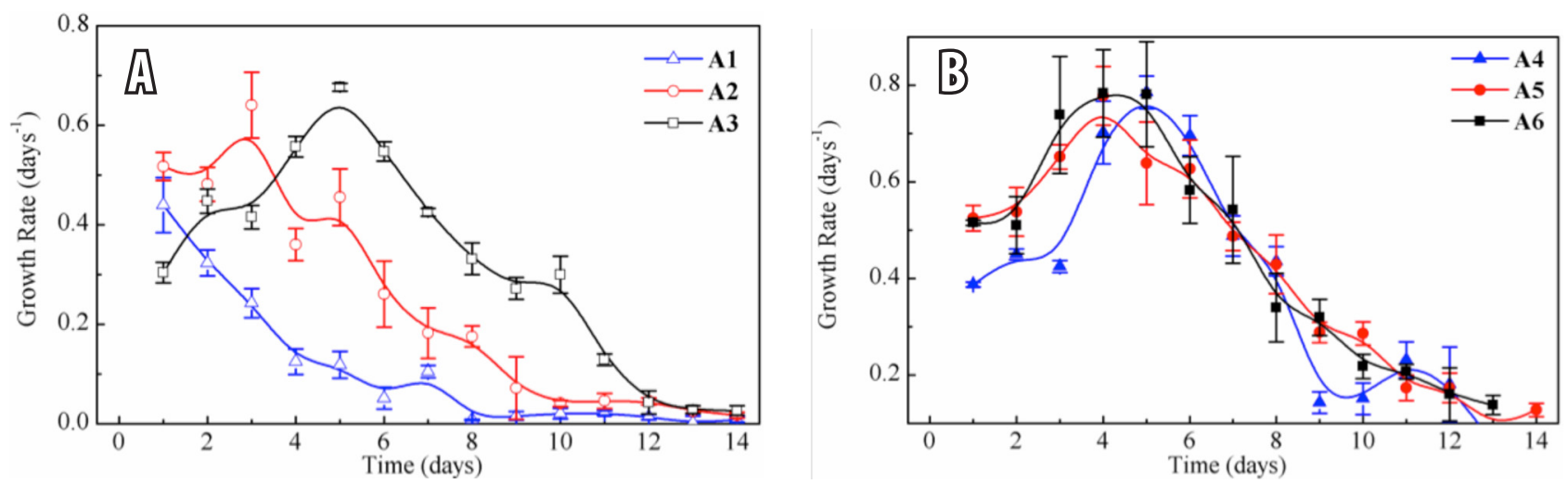

Fig. 4. Diurnal variation of daily-averaged growth rates of algal cultures with different concentrations of nitrogen and phosphorus. Treatments A1, A2, A3 (A); treatments A4, A5, A6 (B).

In contrast, in high nutrient concentration treatments A5 and $\mathrm{A} 6$, the exponential growth period and the maximum growth rate were observed earlier than in A3 and A4 with relatively lower nutrient concentrations, respectively, while there were no significant differences in the maximum AGR. This suggested that high nutrient levels can cause the exponential growth period to occur earlier without significant effect on the maximum AGR.

\section{Relationship between the algal growth rates and the cellular nucleobase ratios}

For each candidate model the corresponding AICc was estimated using the function AICc of AICcmodavg packages in $\mathrm{R}$ software (Table 2). According to Table 2, the M1 model with the smallest AICc value was the 'best' among the models tested. However, no significant differences of Akaike's information criterion $(\Delta \mathrm{i}<2)$ and Adj. R2 were found among these three candidate models. Therefore, according the theory of Akaike's information criterion, all of the candidate models have similar statistical support, because the Akaike differences between models were less than 2. We used the M1 model (logarithmic growth model) for inference (AICc was not the smallest) in this study. This model is expressed as the following equation: $\mu=\mathrm{a}-\mathrm{b} \cdot \ln ([\mathrm{U}] /[\mathrm{T}]+\mathrm{c})$, where $\mu$ is growth rate of algae in a growth phase; $[\mathrm{U}] /[\mathrm{T}]$ is the molar ratio of uracil to thymine; and a, b, c are the constants. The nonlinear regression model (logarithmic growth model) was fitted between algal growth rate and the ratio of [U] to [T] $(r=0.695, p<0.001, n=22)$. Algal growth rate and cellular $[\mathrm{U}] /[\mathrm{T}]$ ratio were obtained during the exponential growth period in above culture experiments. $[\mathrm{U}] /[\mathrm{T}]$ ratios had a range of 1.43 to 7.09 and $\mu$ had a range of 0.15 to 0.66 day $^{-1}$. The relationship between $[\mathrm{U}] /[\mathrm{T}]$ ratios and $\mu$ of algal populations could be described by a logarithmic growth function, suggesting $\mu$ could be effectively retrieved from $[\mathrm{U}] /[\mathrm{T}]$ ratios (Fig. 5). Moreover, the point ([U]/[T] 2.30, $\mu 0.44$ day $^{-1}$ ) of the fitting curve seemed to be an inflection point, as a critical value for the exponential growth phase of algal. In the future, the inflection point using the estimated method of molar ratio of uracil to thymine might have potential use as an early warning value of algal growth rate $\left(0.44\right.$ day $\left.^{-1}\right)$ in a large lake or reservoir just described in this study.

\section{A case study of drinking water reservoir}

$M$. aeruginosa, the dominant species of cyanobacteria, accounted for $73 \%$ of phytoplankton community biomass in surface water of the Qingcaosha Reservoir in October of 2014. The chlorophyll $a$ concentrations varied from 27.7 to $68.2 \mu \mathrm{g} \mathrm{L}^{-1}$. The molar ratios of $[\mathrm{U}] /[\mathrm{T}]$ in algal cells ranged between 1.54 and 3.02. The modeled algal growth rates in the Qingcaosha Reservoir, using molar ratios of uracil to thymine ranged from 0.24 to 0.52 day $^{-1}$, They were comparable to the growth rates determined in eutrophic Biwa Lake and Three Gorges Reservoir based on the frequency of dividing cells technique (Tsujimura 2003; Wang et al. 2010). The observed growth rates were 0.49 and 0.52 day $^{-1}\left(\geq 0.44\right.$ day $^{-1}$, Table 3) at sites QCS1 and QCS2 nearby the reclamation area in Qingcaosha Reservoir, respectively, where the doubling time of algal biomass was less than 1.5 days. The relatively shorter doubling time indicated that the potential risk of algal bloom might be relatively higher beside the reclamation area. The algae cells

Table 2. For each candidate model, the equation, Adj- $\mathrm{R}^{2}$, the small-sample bias-corrected form of Akaike's information criterion AICc, Akaike differences $\Delta \mathrm{i}$

$\begin{array}{lcccc}\text { Model } & \text { Equation } & \text { AICc } & \Delta \mathbf{i} & \text { Adj.-R }^{2} \\ \text { Logarithmic growth } & \mathrm{y}=\mathrm{a}-\mathrm{b} \times \ln (\mathrm{x}+\mathrm{c}) & -39.60 & 0.61 & 0.695 \\ \text { Exponential growth } & \mathrm{y}=\mathrm{a} \times \exp (\mathrm{x} / \mathrm{b})+\mathrm{c} & -39.92 & 0.28 & 0.700 \\ \text { Three-parameter exponential growth } & \mathrm{y}=\exp (\mathrm{a}+\mathrm{b} /(\mathrm{x}+\mathrm{c})) & -40.20 & 0.00 & 0.703\end{array}$




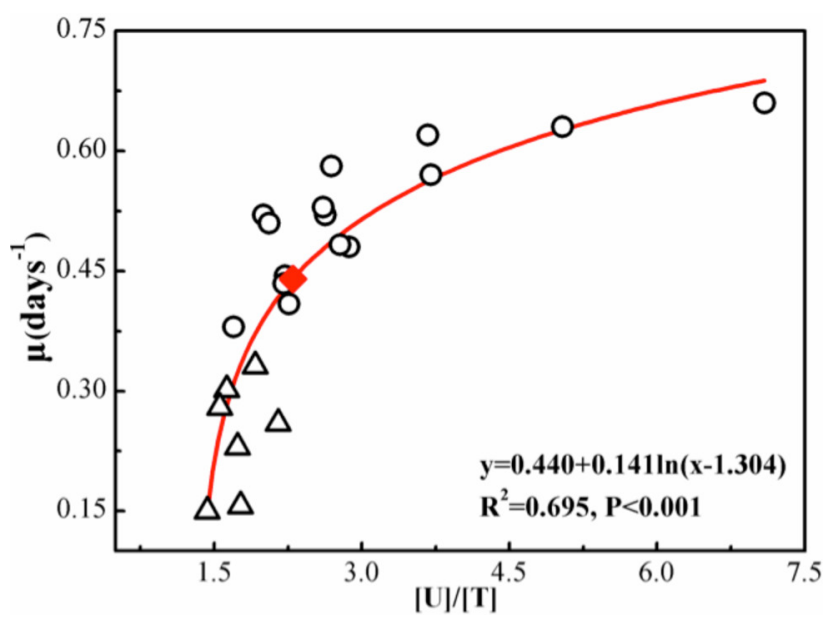

Fig. 5. Relationship between algal growth rates $\left(\mu\right.$, day $\left.^{-1}\right)$ and molar ratios of uracil to thymine ([U]/[T]). Circles indicate algal cell samples collected in the exponential growth period, triangles indicate algal cell samples not in the exponential growth period. Single rhombus point designates the inflection point of the logarithmic regression curve.

tended to accumulate at Site QCS1 of the recirculation zone in the North of reclamation area where the chlorophyll $a$ concentration was up to $68.2 \mu \mathrm{g} \mathrm{L}^{-1}$ (Table 3). This was consistent with previous occurrences of algal bloom in this location, suggesting that high-frequency monitoring and prevention measures should be conducted.

\section{Discussion}

Nucleic acids derived indices (i.e. RNA/DNA ratio) can be applied to estimate in situ growth rate, which reflects the growth characteristics of algae in natural waters. However, the applicability of RNA/DNA ratio is largely limited by the complicated quantitative analysis methods used with a lengthy extraction and purification of DNA and RNA (Berdalet et al. 2005; Caldarone et al. 2006; Greco et al. 2014; Mueller et al. 2014). Uracil and thymine are bases in ribonucleic acid and deoxyribonucleic acid, respectively. The ratios of RNA to DNA, as a widely-used indicator of growth rate of phytoplankton, can also be estimated according to the ratio of [U] to [T] (Glavin et al. 2002; Huang et al. 2012), which can be quantitatively analyzed by HPLC (Huang et al. 2012). Moreover, specific growth rates of M. aeruginosa could even be retrieved directly from the $[\mathrm{U}] /[\mathrm{T}]$ ratios by estimation using the obtained logarithmic growth model (Fig. 5), rather than using RNA to DNA ratios. Other studies have shown that the logarithmic model can be used to explain the relationship between nucleobase ratios and algal growth rates more effectively than other models (Pomati et al. 2004; Cao et al. 2011; Paine et al. 2012).

Once the algal cells are separated from water, filtered and kept in a refrigerator/ice box, the algal cells presumably stop growing immediately and the content of nucleobases remains stable. Thus, the ratio of $[\mathrm{U}]$ to $[\mathrm{T}]$ can reflect the physiological state of algae at the time of sampling, and represent the actual growth rate of algae (i.e., in situ growth rate). Therefore, in situ blue-green algal growth rate in natural water bodies when $M$. aeruginosa was the dominant species, could be estimated by determining the content of nucleobases in algal cells. This method is potentially applicable to estimate growth rate of other micro algal species. Surely, additional laboratory cultures are needed to improve estimation of algal community growth rates based on nucleobase ratio.

The application of $[\mathrm{U}] /[\mathrm{T}]$ ratio to estimate algae growth rates has the potential to be an alternative approach for overcoming the aforementioned disadvantages of traditional methods due to the following reasons: firstly, it was not necessary to measure in situ growth rate by field incubation at each site, which could affect the normal exchange of substances and energy and destroy microbial food webs within the enclosure (Li et al.2012). Secondly, the method of nucleobase analysis was simple and easy to use, especially, suitable and convenient for the investigator to apply in the field. High-frequency sampling and monitoring for a diurnal cycle in each site was not required (Yamamoto,

Table 3. Algal growth characteristics in surface water of Qingcaosha Reservoir. Chl $a$, chlorophyll $a$ concentration; [U]/[T], the molar ratios of uracil and thymine; $\mu$, specific growth rate of algae; $\mathrm{k}$, doublings per day; $\mathrm{T} 2$, doubling time

\begin{tabular}{|c|c|c|c|c|c|c|}
\hline Site & Location & $\begin{array}{c}\text { Chl } a \\
\left(\mu \mathrm{g} \mathrm{L}^{-1}\right)\end{array}$ & {$[\mathrm{U}] /[\mathrm{T}]$} & $\mu\left(\right.$ day $\left.^{-1}\right)$ & $\mathbf{k}$ & T2 (day) \\
\hline QCS1 & $\begin{array}{l}\text { Recirculation zone in the North of } \\
\text { reclamation area }\end{array}$ & 68.2 & 2.74 & 0.49 & 0.71 & 1.41 \\
\hline QCS2 & $\begin{array}{l}\text { Main flow zone in the South of } \\
\text { reclamation area }\end{array}$ & 28.9 & 3.02 & 0.52 & 0.74 & 1.34 \\
\hline QCS3 & The middle of reservoir & 36.6 & 2.12 & 0.41 & 0.59 & 1.69 \\
\hline QCS4 & The middle of reservoir & 32.4 & 1.63 & 0.28 & 0.41 & 2.46 \\
\hline QCS5 & The middle of reservoir & 28.4 & 1.60 & 0.27 & 0.39 & 2.58 \\
\hline QCS6 & The middle of reservoir & 27.7 & 1.83 & 0.35 & 0.50 & 1.98 \\
\hline QCS7 & Water transfer pumping station & 30.7 & 1.54 & 0.24 & 0.34 & 2.93 \\
\hline QCS8 & Tide-blocking drainage sluice & 30.8 & 1.99 & 0.39 & 0.56 & 1.79 \\
\hline
\end{tabular}


Shiah 2010). Substantial labor and taxonomic skill were also not required (Laws 2013). Thirdly, the information of in situ growth rates in greater spatialtemporal scales and at a high-resolution can be achieved. Compared to traditional methods, the spatial and temporal resolution can increase by increasing the sampling frequency according to the requirement of the experiments. We also can potentially forecast the time and location of algal blooms by employing the numerical simulation method (Donaghay, Osborn 1997; Zhang et al. 1997).

Admittedly, it is still unknown whether the method used to estimate in situ growth rates on the basis of nucleobases is universally applicable to other algal species. More additional incubation experiments in the laboratory and further research are needed. Therefore, the relationships between $[\mathrm{U}] /[\mathrm{T}]$ ratio and growth rates with respect to different algal species and in corresponding environmental conditions is also uncertain. These issues are under investigation and further researches are needed to understand in situ growth rate of phytoplankton communities.

\section{Acknowledgements}

This research was supported by the National Natural Science Foundation of China (Grant No. 41071301 and 40601095), the Grants for Swedish-Chinese Research Collaboration (CHEMSTRRES-YRD) and the Science and Technology Commission of Shanghai Municipality (13DJ1400103).

\section{References}

Berdalet E., Roldán C., Olivar M.P. 2005. Quantifying RNA and DNA in planktonic organisms with SYBR Green II and nucleases. Part B. Quantification in natural samples. Sci. Mar. 69: 17-30.

Berges J.A., Varela D.E.,Harrison P.J.2002. Effects of temperature on growth rate cell composition and nitrogen metabolism in the marine diatom Thalassiosira pseudonana (Bacillariophyceae). Mar. Ecol. Prog. Ser. 225: 139-146.

Binder B.J., Liu Y.C. 1998. Growth rate regulation of rRNA content of a marine Synechococcus (Cyanobacterium) strain. Appl. Environ. Microbiol. 64: 3346-3351.

Braunwarth C., Sommer U. 1985. Analyses of the in situ growth rates of Cryptophyceae by use of the mitotic index technique. Limnol. Oceanogr. 30: 893-897.

Burnham K.P., Anderson D.R. 2002. Model Selection and Multimodel Inference: A Practical Information-theoretic Approach. Springer Science \& Business Media.

Caldarone E.M.,Clemmesen C.M., Berdalet E., Miller T.J., Folkvord A., Holt G.J., Olivar M.P., Suthers I.M. 2006. Intercalibration of four spectrofluorometric protocols for measuring RNA/DNA ratios in larval and juvenile fish. Limnol. Oceanogr. Methods 4: 153-163.

Campbell L., Carpenter E.J. 1986. Diel patterns of cell division in marine Synechococcus spp.(Cyanobacteria): use of the frequency of dividing cells technique to measure growth rate. Mar. Ecol. Progr. Ser. 32: 139-148.

Cao C., Zheng B., Chen Z., Huang M.,Zhang J.2011. Eutrophication and algal blooms in channel type reservoirs: A novel enclosure experiment by changing light intensity. J. Environ. Sci. 23: $1660-1670$.

Chícharo M.A., Chícharo L. 2008. RNA: DNA ratio and other nucleic acid derived indices in marine ecology. Int. J. Mol. Sci. 9: 1453-1471.

Chan L.L., Hodgkiss I.J., Wan J.M.F., Lum J.H.K., Mak A.S.C., Sit W.H., Lo S.C.L. 2004. Proteomic study of a model causative agent of harmful algal blooms Prorocentrum triestinum II: the use of differentially expressed protein profiles under different growth phases and growth conditions for bloom prediction. Proteomics 4: 3214-3226.

Chang J., Dam H.G. 1993. The influence of grazing on the estimation of phytoplankton growth rate via cell cycle analysis: modeling and experimental evidence. Limnol. Oceanogr. 38: 202-212.

Cloern J.E., Grenz C., Vidergar-Lucas L. 1995. An empirical model of the phytoplankton chlorophyll: carbon ratio-the conversion factor between productivity and growth rate. Limnol. Oceanogr. 40: 1313-1321.

Dawes C.J. 1998. Marine Botany. John Wiley \& Sons Canada.

Donaghay P.L., Osborn T.R. 1997. Toward a theory of biologicalphysical control of harmful algal bloom dynamics and impacts. Limnol. Oceanogr. 42: 1283-1296.

Dortch Q., Roberts T.L., Clayton Jr J., Ahmed S. 1983. RNA/DNA ratios and DNA concentrations as indicators of growth rate and biomass in planktonic marine organisms. Mar. Ecol. Progr. Ser. 13: 61-71.

Elser J.J. 1992. Phytoplankton dynamics and the role of grazers in Castle Lake California. Ecology 73: 887-902.

Gieskes W., Kraay G. 1989. Estimating the carbon-specific growth rate of the major algal species groups in eastern Indonesian waters by ${ }^{14} \mathrm{C}$ labeling of taxon-specific carotenoids. Deep Sea Res. 36: 1127-1139.

Glavin D.P., Schubert M., Bada J.L. 2002. Direct isolation of purines and pyrimidines from nucleic acids using sublimation. Anal. Chem. 74: 6408-6412.

Greco M., Sáez C.A., Brown M.T., Bitonti M.B. 2014. A simple and effective method for high quality co-extraction of genomic DNA and total RNA from low biomass Ectocarpus siliculosus the model brown alga. PLoS One 9:e96470.

Hoffmann W.A., Poorter H. 2002. Avoiding bias in calculations of relative growth rate. Ann. Bot. 90: 37-42.

Hou J., Lai H., Lei H., Huang B. 2008. Study on detection of in situ growth rate of Tankayama pulchellum. Acta Hydrobiol. Sin. 32: 141-147. (in Chinese)

Huang Q., Kaiser K., Benner R. 2012. A simple high performance liquid chromatography method for the measurement of nucleobases and the RNA and DNA content of cellular material. Limnol. Oceanogr. Methods 10: 608-616.

Jin X., Tu Q. 1990. Investigation Guideline of Lake Eutrophication. Press of China Academy of Environmental Sciences, Beijing. (in Chinese)

Katsanevakis S. 2006. Modelling fish growth: model selection multi-model inference and model selection uncertainty. Fisheries Res. 81: 229-235.

Katsanevakis S., Maravelias C.D. 2008. Modelling fish growth: multi-model inference as a better alternative to a priori using von Bertalanffy equation. Fish Fisheries 9: 178-187.

Kerkhof L., Ward B. 1993. Comparison of nucleic acid hybridization and fluorometry for measurement of the relationship between RNA/DNA ratio and growth rate in a marine bacterium. Appl. Environ. Microbiol. 59: 1303-1309. 
Laws E.A. 2013. Evaluation of in situ phytoplankton growth rates: a synthesis of data from varied approaches. Annu. Rev. Mar. Sci. 5: 247-268.

Li Z., Xie D., Guo J., Long M., Sun Z., Chen Y. 2012. Preliminary study on in situ growth rate of dominant algae species in Pengxi River of the Three Gorges Reservoir. J. Lake Sci. 24: 746-754. (in Chinese)

Loughna P., Goldspink G. 1984. The effects of starvation upon protein turnover in red and white myotomal muscle of rainbow trout Salmo gairdneri Richardson. J. Fish. Biol. 25: 223-230.

Ma J., Qin B., Wu P., Zhou J., Niu C., Deng J., Niu H. 2015. Controlling cyanobacterial blooms by managing nutrient ratio and limitation in a large hyper-eutrophic lake: Lake Taihu China. J. Environ. Sci. 27: 80-86.

Ma Z., Niu Y., Xie P., Chen J., Tao M., Deng X. 2013. Off-flavor compounds from decaying cyanobacterial blooms of Lake Taihu. J. Environ. Sci. 25: 495-501.

McDuff R., Chisholm S. 1982. The calculation of in situ growth rates of phytoplankton populations from fractions of cells undergoing mitosis: A clarification. Limnol. Oceanogr. 27: 783-788.

Monon J. 1949. The growth of bacterial cultures. Annu. Rev. Microbiol. 3: 371-394.

Mueller J.A., Culley A.I., Steward G.F. 2014. Variables influencing extraction of nucleic acids from microbial plankton (viruses bacteria and protists) collected on nanoporous aluminum oxide filters. Appl. Environ. Microbiol. 80: 3930-3942.

Pápista É., Ács É., Böddi B. 2002. Chlorophyll-a determination with ethanol - a critical test. Hydrobiologia 485: 191-198.

Paerl H.W., Fulton R.S., Moisander P.H., Dyble J. 2001. Harmful freshwater algal blooms with an emphasis on cyanobacteria. Sci. World J. 1: 76-113.

Paine C., Marthews T.R., Vogt D.R., Purves D., Rees M., Hector A., Turnbull L.A. 2012. How to fit nonlinear plant growth models and calculate growth rates: an update for ecologists. Methods Ecol. Evol. 3: 245-256.

Pel R., Floris V., Gons H.J., Hoogveld H.L. 2004. Linking flow cytometric cell sorting and compound-specific ${ }^{13} \mathrm{C}$-analysis to determine population-specific isotopic signature and growth rates in cyanobacteria-dominated lake plankton. J. Phycol. 40: 857-866.

Pomati F., Netting A.G., Calamari D., Neilan B.A. 2004. Effects of erythromycin tetracycline and ibuprofen on the growth of Synechocystis sp. and Lemna minor. Aquatic Toxicol. 67: 387-396.

Redalje D., Laws E. 1981. A new method for estimating phytoplankton growth rates and carbon biomass. Mar. Biol. 62: 73-79.

Stolte W., Garcés E. 2006. Ecological aspects of harmful algal in situ population growth rates. In Garneli E.,Turner J.T. (eds) Ecology of Harmful Algae. Springer, pp. 139-152.

Tsujimura S. 2003. Application of the frequency of dividing cells technique to estimate the in situ growth rate of Microcystis (Cyanobacteria). Freshwater Biol. 48: 2009-2024.

Wang L., Cai Q., Zhang M., Xu Y., Kong L., Tan L. 2010. Estimating in situ growth rate of Microcystis by FDC technique with comparision of different sampling periods-a case of study from Xiangxi Bay Three Gorges Reservoir China. Fresenius Environ. Bull. 19: 1576-1581.

Wang L., Liu L., Zheng B. 2013. Eutrophication development and its key regulating factors in a water-supply reservoir in North China. J. Environ. Sci. 25: 962-970.

Xu S., Huang B. 2010. Photopigment radiolabelling as a tool for determining group-specific phytoplankton photosynthesis rate and grow th rate. J. Oceanogr. Taiwan Strait 29: 478-487.

Yamamoto Y., Shiah F.-K. 2010. Relationship between cell growth and frequency of dividing cells of Microcystis aeruginosa. Plankton Benthos Res. 5: 131-135.

Yamamoto Y., Tsukada H. 2009. Measurment of in situ specific growth rates of Microcystis (Cyanobacteria) from the frequency of dividing cells. J. Phycol. 45: 1003-1009.

Zhang Y., Huang C., Wang X., Zheng B. 1997. Ecodynamic models accounting for the changes in lake ecosystem. J. Environ. Sci. 9: 141-148.

Zwietering M., Jongenburger I., Rombouts F., Van't Riet K. 1990. Modeling of the bacterial growth curve. Appl. Environ. Microbiol. 56: 1875-1881. 